THE LANGUAGE OF LITERATURE

General Editor: N. F. Blake

Professor of English Language and Linguistics

University of Sheffield 


\section{THE LANGUAGE OF LITERATURE}

General Editor: N. F. Blake

Published titles

An Introduction to the Language of Literature N. F. Blake The Language of Shakespeare N. F. Blake

The Language of Chaucer David Burnley

The Language of Wordsworth and Coleridge Frances Austin

The Language of Irish Literature Loreto Todd

The Language of D. H. Lawrence Allan Ingram

The Language of Thomas Hardy Raymond Chapman

The Language of Drama David Birch

The Language of Jane Austen Myra Stokes

The Language of the Metaphysical Poets Frances Austin

Further titles are in preparation.

Other books by Frances Austin

The Letters of William Home Clift 1803-1832 (Meldon House) Robert Clift of Bodmin: Able Seaman 1790-1799 (Meldon House) The Clift Family Correspondence 1792-1846 (The Centre for English Cultural Tradition and Language, University of Sheffield) 


\section{The Language of the Metaphysical Poets}

FRANCES AUSTIN

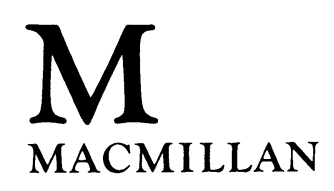


(C) Frances Austin 1992

Softcover reprint of the hardcover 1st edition 1992

All rights reserved. No reproduction, copy or transmission of this publication may be made without written permission.

No paragraph of this publication may be reproduced, copied or transmitted save with written permission or in accordance with the provisions of the Copyright, Designs and Patents Act 1988, or under the terms of any licence permitting limited copying issued by the Copyright Licensing Agency, 90 Tottenham Court Road, London W1P 9HE.

Any person who does any unauthorised act in relation to this publication may be liable to criminal prosecution and civil claims for damages.

First published 1992 by

THE MACMILLAN PRESS LTD

Houndmills, Basingstoke, Hampshire RG21 2XS

and London

Companies and representatives

throughout the world

ISBN 978-0-333-49567-4 ISBN 978-1-349-21963-6 (eBook)

DOI 10.1007/978-1-349-21963-6

A catalogue record for this book is available from the British Library.

Typeset by LBJ Enterprises Limited

of Chilcompton and Tadley 


\section{Contents}

Prefatory Note vii

Acknowledgements ix

Grammatical Terminology xi

Note on Texts xiii

Chronological Chart xiv

1 Introduction 1

2 John Donne (1572-1631) 18

3 George Herbert (1593-1633) 47

4 Richard Crashaw (1612-49) 75

5 Henry Vaughan (1621-95) 100

6 Thomas Traherne (1637-74) 127

7 Analysis of Passages 155

8 Conclusion 166

Appendix 1 Hermetic Philosophy 172

Appendix 2 The Cambridge Platonists 176

$\begin{array}{ll}\text { Notes } & 178\end{array}$

Select Bibliography and Further Reading 185

Index 1 Literary and Historical References 189

Index 2 Language Topics 191 
For

JEAN

who gave me my first book of poems

and

PATRICIA

who taught me 'grammar' 


\section{Prefatory Note}

Such phrases as 'metaphysical poetry' and 'metaphysical poets' ('the metaphysicals') are widely used and understood but it is hard to define them. Dryden first used the term 'metaphysical' in this context in 1693 in A Discourse Concerning the Original and Progress of Satire. Praising the poems of the Earl of Dorset, he said that Donne 'affects the metaphysics ... and perplexes the minds of the fair sex with nice speculations of philosophy'. What this means is not clear, but the word stuck. Pope is said to have called Donne's poetry 'metaphysical' (Spence's Anecdotes, 1744). His opinion of it may best be understood from a section of his Imitations of Horace (1737): 'The Satires of Dr John Donne, Dean of St Paul's, Versified'. Better known is Johnson's grouping, in his 'Life of Cowley', of a number of the seventeenthcentury poets as 'metaphysical poets' (Lives of the Poets, 1779-81).

Etymologically, 'metaphysical' means 'behind or beyond the physical'. It is also defined as 'being concerned with first principles and the essence of Being and Knowing'. Such notions neatly encompass the work of the religious and meditative poets Donne, Herbert, Crashaw and Vaughan, whose verse is the subject of this short book.

In whatever light we set these poets, however, Donne and his poetry stand out. Until the twentieth century the word 'metaphysical', when used in discussions of English poetry, was abusive and it is clear that it was Donne's poetry that called this forth. Likewise, twentieth-century comment on the metaphysical poets gives Donne's work far more space and consideration than that of the other three poets here named. A reason for this may be suggested. Herbert, Crashaw and Vaughan - the same goes for Traherne, the fifth of our poets - are religious and meditative 
writers whose secular verse, where it exists, is of far less importance. Donne's religious poetry, however, even when what may be called his philosophical poetry is added to it, does not amount to half of his poetical output. Furthermore, his secular poetry is still widely read - perhaps even more widely read than his religious verse. Much of this secular poetry was written in the 1590 s and the first decade of the seventeenth century, before most of the religious verse, and it is in this early work that Donne first used the linguistic features that are the hallmark not only of his own poetry but of that of much of the later metaphysical poets also. To discuss the language of Donne's poetry without reference to his secular verse would be unreasonable and I have therefore widened my brief to take it in. Many of Donne's religious poems are sonnets and it would not be possible to demonstrate fully from this form alone those features of dramatic and conversational tone that depend on metrical variation.

Traherne's poetry has been read only since its first publication in 1903. Yet he died long before Vaughan and his subject matter is wholly religious. It therefore seemed worth while to examine his poetry within the context of the generally acknowledged - if vague - metaphysical canon. The language of religious devotion gives common ground for comparison. Because Traherne's poetry was composed after the Commonwealth and he is in some ways isolated from the more closely-knit earlier group, I have adopted a slightly different way of looking at his language from that used for the other four poets.

East Stour, Dorset

Frances Austin

October 1990 


\section{Acknowledgements}

In the course of writing this book I have been fortunate to have the help and encouragement of friends and colleagues. Helen Wilcox has supplied me with much bibliographical information; Katie Wales has phototcopied articles and sent books that I could not obtain elsewhere; Bernard Jones has read and re-read the various drafts and made many suggestions; and John Gibson has painstakingly read through the whole script. To all these people I am most grateful. They are not, of course, responsible for any errors or shortcomings. As always, Professor Norman Blake has been a firm and faithful support.

I am also much indebted to the staff of Sherborne County Library and the Dorset Inter-Library Loan Service for their time and patience in tracing and borrowing books. Without their assistance this book could not have been written. 


\section{Grammatical Terminology}

Inevitably in a book of this kind grammatical terms must be used even if they are kept to a minimum. Some readers may be unfamiliar with even 'traditional' terminology and others may be used to different terms of the various current grammatical 'models'.

In this book, the traditional terms for the 'parts of speech' noun, verb, adjective, etc. - have been used. For describing the basic sentence or clause structure the model of Systemic Grammar has generally been followed. Subject, Verb and Complement (S V C) are the main syntactical groups that make up the clause. The term Complement includes both the Object and Complement of 'traditional' grammar. Subjects and Complements are often 'realised' by nominal groups. A nominal group is a group of words centred on a noun which is called the 'head' of the group. An example is 'the cross little girl with black curls which look like corkscrews'. Girl is the 'head' of the group; the words coming before are pre-modifiers and those after make up the postmodification. Premodifiers are usually single words. Post modifiers are often prepositional groups, such as with black curls, or clauses, usually relative clauses: which look like corkscrews. Complements are also 'realised' by adjectives or adjectival phrases when they follow the verb to be or other copular verbs such as seem. Verbs are 'realised' by verbal groups. These may consist of a single verb or a verb preceded by one or more auxiliary verbs. 'Her mother smacked her' is an example of the first kind and 'I would have smacked her if I had been her mother' of the second. Note that the verb which conveys the 'main' information (called a 'lexical' or 'lexically full' verb) comes last in the group. The other main groups in a clause are adverbials, either single words such as happily or adverbial 
groups such as with her doll; for a while. Adverbials can occur in strings, as in 'She played happily / with her doll / for a while'.

It is now customary in Systemic Grammar to discard the term 'sentence' and substitute 'clause complex'. Readers will find both terms used in this book. 'Sentence' seems too useful a term to be rejected completely, but at times 'clause complex' is clearer and more precise because it indicates the clause structure of which the sentence is composed and the way in which those clauses are put together.

Most books based on Systemic Grammar mark the verbal group with a $\mathbf{P}$ for Predicator. V seems more accessible to those unfamiliar with this model, so it has been adopted here. An exposition of Systemic Grammar will be found in Dennis Freeborn, A Course Book in English Grammar (Macmillan, 1987). A useful introductory book on grammar that shows the relation of traditional grammar to the Systemic model is N. F. Blake, Traditional English Grammar and Beyond (Macmillan, 1988).

For grammatical terms and explanations other than those used in Systemic Grammar, I have used Randolph Quirk et al., A Comprehensive Grammar of the English Language (Longman, 1986). Definitions of rhetorical terms and further information on them may be found in Katie Wales, $A$ Dictionary of Stylistics (Longman, 1989). A book in this series that covers most aspects of the language and terminology used is N. F. Blake, An Introduction to the Language of Literature (Macmillan, 1990). 


\section{Note on Texts}

The poems of each of the five poets examined here have been quoted from the Oxford English Texts editions. Details of individual volumes will be found in the Bibliography. For Traherne, the edition by Gladys Wade (1932) has also been used and readers are recommended to consult it for the sequence of Traherne's poems as the arrangement is clearer than that in Margoliouth's edition (1958). In the chapter on Vaughan I have drawn extensively on the notes in the edition of Alan Rudrum (1976). Further comments on manuscripts and text status are included in the first note for each chapter where appropriate.

Quotations from Sidney and Spenser in Chapter 1 are taken from the Oxford English Texts editions: The Poems of Sir Philip Sidney, ed. William A. Ringler Jr (Oxford: Clarendon Press, 1962); Spenser's Faerie Queene, ed. J. C. Smith (Oxford: Clarendon Press, 1909, repr. 1978) 2 vols. The edition used for quotations from Shakespeare is William Shakespeare: the Complete Works, eds Stanley Wells and Gary Taylor (Oxford: Clarendon Press, 1986). 


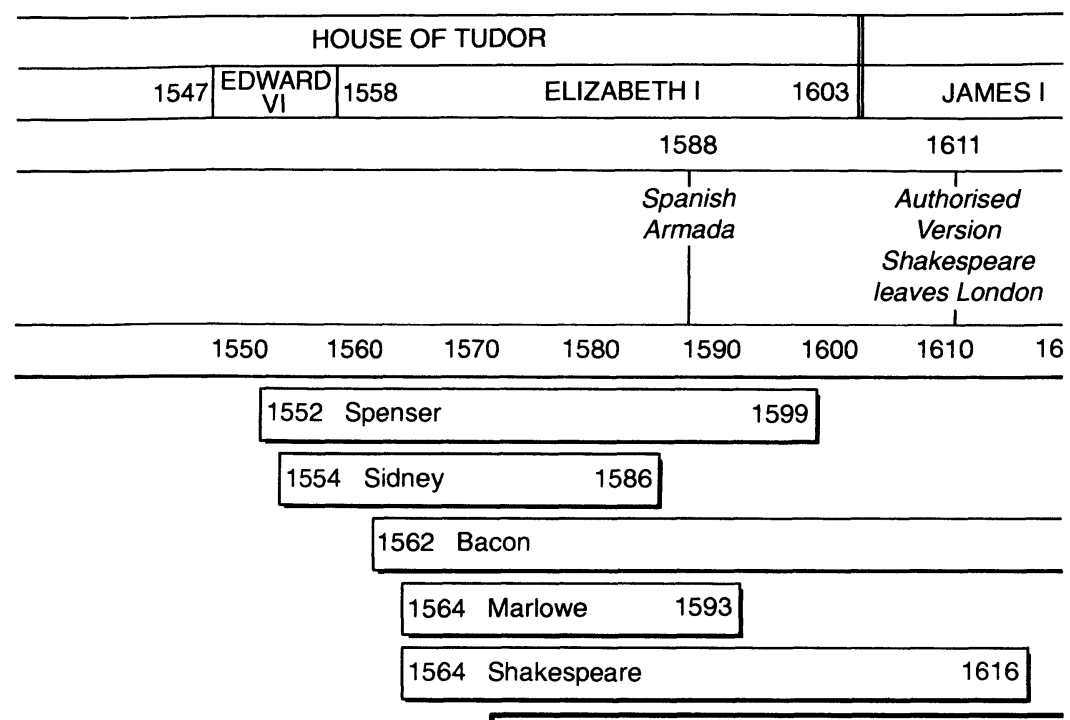

1572 JOHN DONNE

1573? Ben Jonson

1588 Hobbes

1592 Quarles

1593 GEORGE HERBERT

1593 Walton

1608 Milton

1612

\section{Chronological Chart}




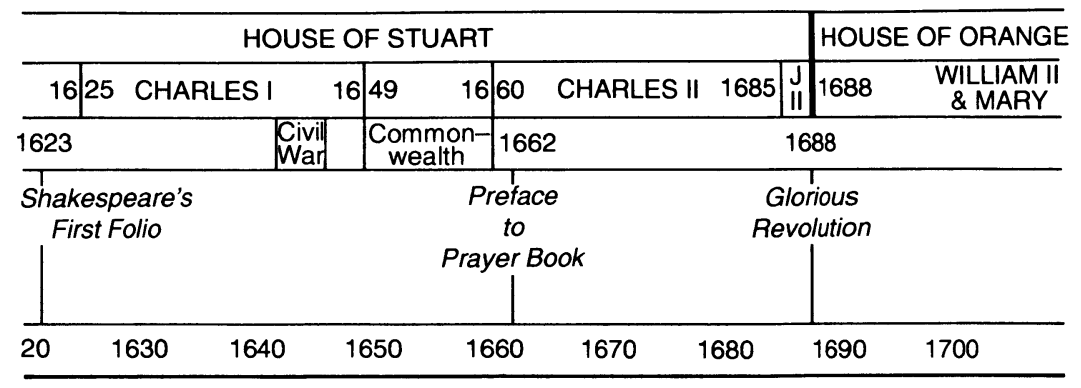

RICHARD CRASHAW 1649

\begin{tabular}{lll}
\hline 621 & Marvell & 1678 \\
\hline
\end{tabular}

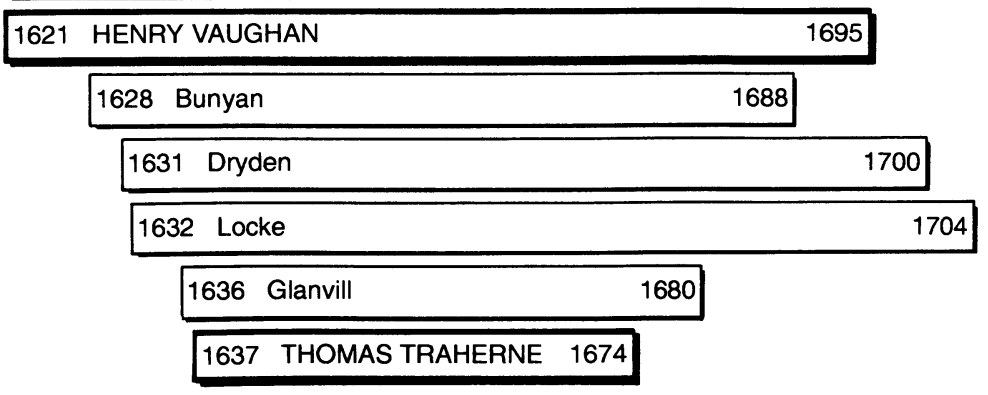

